\title{
MAPPING SOUTH CHINA SEA REGION BY GMT FOR MARINE GEOLOGICAL ANALYSIS AND VISUALIZATION
}

\author{
Polina LEMENKOVA* \\ Ocean University of China, College of Marine Geo-sciences, Qingdao, China, \\ ORCID ID: 0000-0002-5759-1089, e-mail: pauline.lemenkova@gmail.com
}

\begin{abstract}
Citation: Lemenkova, P. (2020). Mapping South China Sea Region by GMT for Marine Geological Analysis and Visualization. Analele Universităţii din Oradea, Seria Geografie, 30(1), 107-121. https://doi.org/10.30892/auog.301112-847
\end{abstract}

\begin{abstract}
The study details geological analysis of the South China Sea region. South China Sea is a marginal sea located in unique geographical region of west Pacific Ocean. It has a complex tectonics history being developed at subduction zone of three tectonic plates: Eurasian, Pacific and Indian. Geologically, South China Sea is rich in mineral resources and has high geological prospects. Within the scope of the study, the review of the general settings of the study area (bathymetry, geology, tectonics and sedimentation) is accomplished by the report on the current activities, methods and research clusters. Current directions in the marine geological research in the South China Sea area are presented. Research methods of the seafloor surveying and mapping currently undertaken in the South China Sea region are described: systematic measurement by multi-beam echo-sounders, altimetric measurements, GPS positioning, application of the unmanned underwater vehicles, GIS mapping, data analysis, dredging and drilling. The results include maps visualized by means of Generic Mapping Tools (GMT) showing geological and geophysical settings in the South China Sea region, bathymetry and model of the marine free-air gravity. Research development and recent progress in marine geologic investigations are reported with focus on current activities in the coastal area of the South China Sea region.
\end{abstract}

Key words: South China Sea, marine geology, Pacific Ocean, research policy

$$
* \quad * \quad * \quad * \quad * \quad *
$$

\section{INTRODUCTION}

Systematic ocean exploration in the $20^{\text {th }}$ century started on ships, naval or merchant navies in different countries. However, the diversity of the scientific tasks and the need to study different research objects in the ocean resulted in the diversification of the research branches, as well as specialized geological and geophysical vessels, equipment and tools. Generally, ocean research fleet consists of vessels of various state and departmental affiliation. They are designed for specialized study of the seafloor relief, marine biological and geological resources, geophysics, multilateral study 
of the ocean water properties, atmosphere layers. Special units of the scientific fleet include drilling vessels and drilling platforms, as well as underwater manned vehicles.

A variety of factors determine the importance of the marine research for China: large territory, dense population, location surrounded by seas on the south and east, vast ocean resources and long coastline. Therefore, the development of the marine geology program on the governmental level is highly actual. The organization of the geological research at the international level is one of the most important problems of the marine geology discussed at international geological congresses. Multidimensional aspects of the marine geology program around South China Sea region are maintained and being developed (Jin, 1989). Cross-institutional arrangement impacts ocean governance in various ways. Interdisciplinary science has links between the geology and oceanography, including exploitation and protection of the marine environment and resources, marine economy, ocean policy, regulation of ocean management, application and resources of the marine science and technologies, development of harbour facilities and coastal engineering (Cai, 1989).

Coastal and marine geology expertise contributes to the environmental mission, providing impartial information on the health of marine ecosystems and environment around Hainan and Taiwan Islands (Lin and Kangming, 1983), natural hazards (tsunami), natural resources, impacts of the climate change, core science systems enabling timely forecasting, relevant and usable information. Institutional arrangement is both critical and essential element in ocean governance. Through cross-institutional arrangement in China, marine geology research and survey laboratories began to make efforts for the establishment of integrated ocean policy such as introduction of new legal actions, policy strategy, or comprehensive planning systems.

\section{METHODS}

Various methods have been developed for successful application at the depths of the ocean seafloor of the continental margins using underwater photography, acoustic, GIS and remote sensing methods. These methods were applied towards studies of the South China Sea region. Eastern tropical part of the Pacific Ocean was recently surveyed in the scope of a program aimed at understanding distribution of the ferromanganese clusters located at the seafloor basement, carried at depths from 4400 to $5100 \mathrm{~m}$ with the use of a 1-5 m above the seafloor of installed underwater cameras. Survey technical means and equipment at South China Sea Institute of Oceanology include modern facilities, remote sensing devices, GIS, drilling equipment that increased significantly since 1960s (Wyrtki, 1961). Applied methods include high-resolution airborne geophysical surveying, land magnetic and resistivity surveying, natural electrical field methods, induced polarization and transient electromagnetic techniques, gravity surveying. It conducts integrated mapping of the coastal environment and marine geology to define offshore hazards and sediment processes, support habitat and resource management, monitor changes.

Multi-beam echo sounder measurements are a basic method to measure the seafloor depth, with an example of the Hydrosweep DS (Caress and Chayes, 1996). It is the basis for all subsequent geological, geophysical research works and theoretical developments. Application of the multi-sounder devices for bathymetric mapping (echo-sounder recorders) is closely related to the accuracy of bathymetric maps. Echo-sounder devices increase the number of measurements, improve their accuracy and expand research scope. The multi-beam sonar echo-sounder was invented in late 1970s. It opened new opportunities for detailed study and mapping of the submarine topography. Special feature of the multi-beam echo sounders consists in the hundreds sound beam sent to the seafloor. The fan beams diverge from the emitter along the axis of the vessel, and enable bathymetric survey with a wide band (from $70 \%$ of the depth to three or more depths, at depth of $5000 \mathrm{~m}$, a band of $15,000 \mathrm{~m}$ can be mapped). Currently, multi-beam echo sounders of various designs (181-rays and more) are installed worldwide on ca. 1,000 vessels. Technical parameters of all modern echo sounders installed on Chinese research vessels include radiating and receiving antennas, subsystems radiation intake, control of onboard pitching and rolling sweeps, special blocks for digital processing to visualize bathymetry in real-time. 
Precise surveying of multi-beam echo-sounder enabled complex detailed geological and geophysical surveys of the seafloor. For decades, study of the seafloor was conducted along the ship by route measurements. Large distances between the ticks did not allow data to correlate with a high degree of reliability. Along with recent technical progress, all types of oceanic morphostructures of the Ocean are detected and discovered. Discovered submarine relief forms include large forms (mid-oceanic ridges, uplands, plateaus, gutters, fault zones) and small forms (separate mountains, underwater canals). The details of the study significantly improved after the organization of work on landfills - limited areas within which parallel tracks are located at the distances of 2-5 miles.

Seafloor survey by multi-beam echo sounders includes a set of the equipment, profiler, magnetometer, gravimeter, side-scan sonar and continuous seismic profiling. Studies of the landforms are accompanied by the station research collecting various geophysical data. As the ship follows straight line, the transducers sends multiple sound pulses to the seafloor sent in many directions simultaneously. When the pulses hit the seafloor, they reflect back to the ship to be detected by the receiver. The multi-beam system then calculates the angle, the time it took for the pulses to travel, the ship's orientation to the water to determine the depth of the seafloor at that spot. Once the data pulses return and are analysed by a computer, the topography of the seafloor is mapped. To "ground-truth" mapping data divers or remotely operated vehicles are used to verify the data collected onboard of the ship. Navigation is important goal for safety of the marine survey, geological and geophysical research. Main method determining the location of the vessel is a GPS system of satellite navigation. A large number of satellites enable to locate vessels, including submarines, up to meters away, regardless of the location of the work area.

Seismic methods of the seafloor mapping are the most important ones to study structure and sedimentary cover of ocean (structure, velocity characteristics): (Lisitsyn et al., 1990; Morgan, 1974; Pushcharovsky and Neprochnov, 1984; Heuret and Lallemand, 2005). Depending on the radiation frequency, the depth of the penetration energy into the sedimentary cover or deeper horizons may change. High-frequency single-channel (continuous seismic profiling) multi-channel methods, as well as deep seismic sounding can be distinguished by the frequency of radiation. The principle of the seismic method of seafloor survey is based on the energy penetration issued by the compressed air, electric discharge, into the water column and then into the rock. After reflection of the signal from the sedimental horizons, the reflected signal goes back to the ship and is received by the antenna (a seismic streamer). The received data is accumulated digitally on a seismic station. Further processing is completed on the computer stations by software that filters out the acoustic noise and store information on the structure of the Earth's crust. There are many modifications of the equipment, such as bottom stations, radio beacons. A set of the equipment designed to study gravimetric, magnetic fields, together with lateral-view sonar, profiling and other geological and geophysical equipment. Example of the gravimetric map is given on figure 3. Special immersible robot is mixed over the ocean floor at an altitude of 300-400 m. The side-scan sonars are designed to study the morphology of the bottom, identify faults in the oil pipelines, and search for sunken objects (ships) of any size with a high degree of resolution. The principle of their operation is based on irradiation of the bottom surface with a frequency of about $6.5 \mathrm{kHz}$.

The study of the seafloor is possible not only through vessels, but by means of satellites from space. Systematic measurement of the surface height (altimetry) of the world ocean water level by the satellite radar at an altitude of ca. $800 \mathrm{~km}$ with accuracy of several meters proved that water level depends on the topography of the seafloor and density of the underlying rocks. Positive relief forms attract water body increasing the height of its surface and vice versa. Figurative concept of the "world ocean level" is not permanent, and differences in the height of the water surface can be more than a hundred meters. Analysis of the ocean altimetric data enabled to create a mathematical model of the relief of the entire oceans, the so-called predicted topography with a high degree of reliability. Satellite data were compared with real echo sounder measurements and extrapolated to unexplored regions. 
Among other research techniques currently used by Chinese researchers for the seafloor surveying and mapping is the Unmanned Underwater Vehicles (UUV). The UUV are any vehicles able to operate underwater without humans. The UUV are used to solve both theoretical and practical problems (inspection of underwater parts of engineering structures, pipelines). In the deep-sea trenches, UUV are used to test the rocks of the seafloor, direct observations of the geological structure, collection of information about the pelagic world, benthos or the properties of the aquatic environment. A breakdown of the oceanic crust on the transverse ridge in the Atlantic Ocean was discovered by UUV apparatus. UUV are widely used to study active and inactive hydrothermal fields that may cause ore formation (Butuzova, 2003). The UUV may be divided into two categories: remotely operated underwater vehicles, controlled by a remote human operator, and autonomous underwater vehicles operating independently, a kind of robot. The accuracy of the predicted topography enabled to plan marine expedition paths (choose areas, tracks), to make major theoretical generalizations. However, it should be stressed that it cannot completely replace the echo-sounder in-situ surveying.

Dredging and drilling are other methods to study the seafloor. Testing bottom rocks through rocks extraction from the seafloor is used by various tools: tubes, dredges, pipes, trawls, scoops. Tube testing is primarily intended to study the upper layers $(<50 \mathrm{~m})$ of the sedimentary cover pressed by its own weight. The tube penetrates at a high speed to the ocean bottom and takes a column of the seafloor sediments into the hollow part of the instrument. In some cases even the bedrock may be taken. Although a complete section of oceanic crust has not yet been drilled, it helps understand the seafloor. Some of them are the samples recovered from the seafloor by drilling or dredging (an underwater rock excavation). Dredging is one of the main methods that allow taking samples of the bedrock from any depths at depths 20 to $6000 \mathrm{~m}$. The most important and evident trend in the recent development of the marine geology policy is advanced made in research on ocean resources and related applications and commercialization of resources for the development of marine science, technology and industry. This included following activities:

1. supported research on ocean resources and related applications;

2. commercialization of the research on ocean resources;

3. development of science and technologies in the marine industry;

4. supported research on ocean and polar science and technology policies and institutions;

5. fostering professionals in the marine sector and public services;

6. development, inspection, repair of marine-related equipment, machinery and technology;

7. establishment and operation of the infrastructure, marine science research stations.

Funded research and technology partnerships with domestic and overseas universities focused on marine geology resulted in a variety of publications on China South Sea geology (Ren et al., 1980). Ocean governance includes essential elements: ocean policy, institutional arrangement, implementation of ocean policy, coordination and cooperation between the sectors and policy constituency.

\section{RESULTS}

Current study is based on cartographic mapping by Generic Mapping Tools (GMT), successfully tested in previous studies. The advantages of the GMT lie in its advanced cartographic solutions, shell scripting approach, open source availability and compatibility with both UNIX and MacOS environment. All maps presented below are made by author using various GMT modules using described methods (Lemenkova, 2019b, 2019c, 2019d). General methods of the marine research described above are cost-expensive and require organization and cooperation, while mapping and spatial analysis and data visualization by GMT are available for anybody which is valuable for researchers. The test study area presented below is South China Sea area.

South China Sea is a unique geographical region, a marginal sea located in the west Pacific Ocean, at the junction of 3 tectonic plates: Eurasian, Pacific and Indian. Geographical location of the South China Sea is between $2^{\circ} 30^{\prime} \mathrm{E} 23^{\circ} 30^{\prime} \mathrm{N}$ and $99^{\circ} 10^{\prime}-121^{\circ} 50^{\prime} \mathrm{E}$ (figure 1). South China 
Sea is surrounded by China mainland, Indo-China Peninsula, greater Sunda Islands, and the Philippines Islands having length from south to north of ca. $3100 \mathrm{~km}$, width from east to west of ca. $1200 \mathrm{~km}$, area of $350 * 104 \mathrm{~km}^{2}$ (Xu et al., 1997).

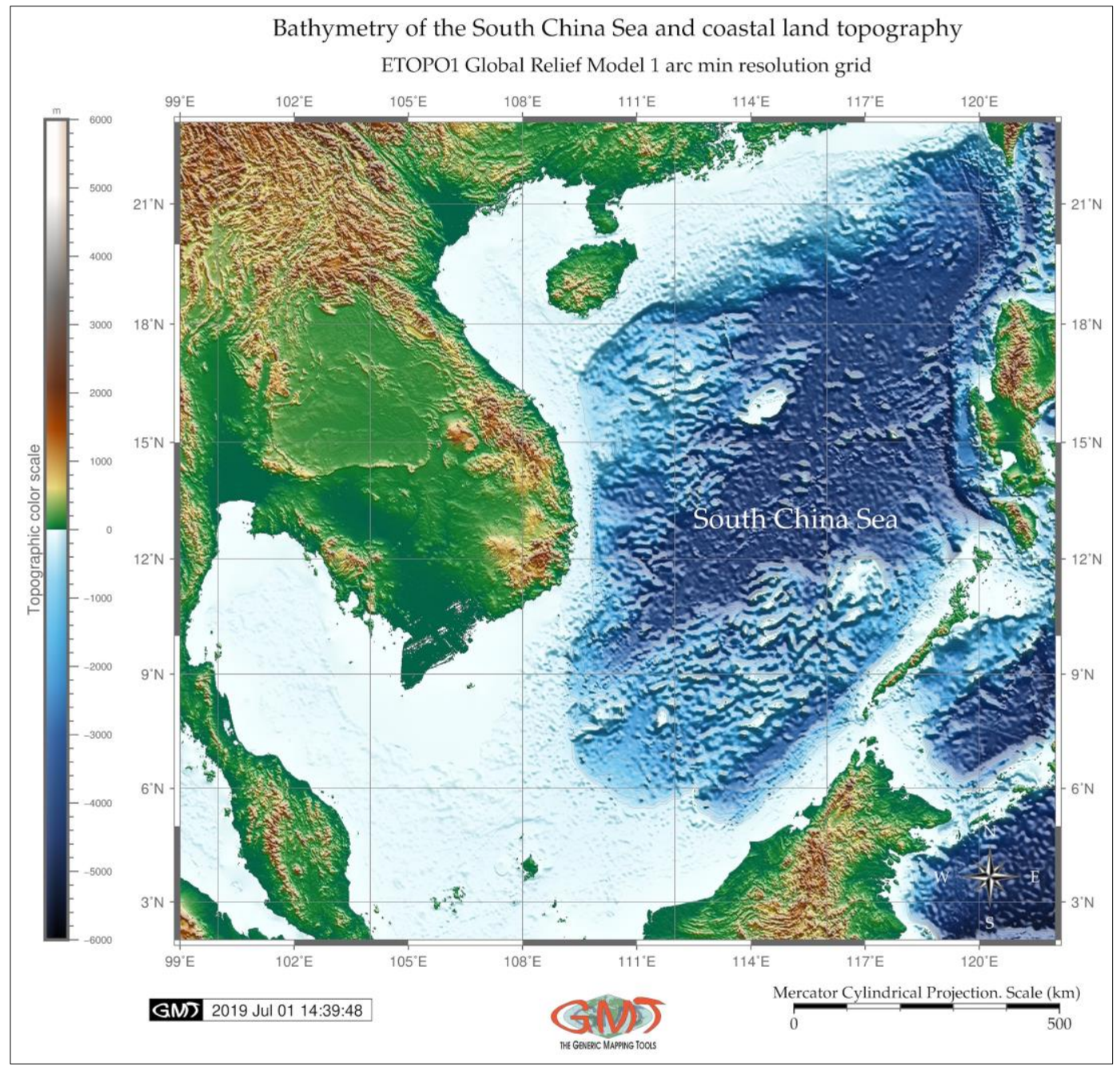

Figure 1. Bathymetric general map of the South China Sea (Source: Author)

South China Sea is one of the marginal seas in western Pacific adjacent to the Southeast Asia, consisting of a deep-sea basin and a terrain system (Jin and Ke, 1990). The special geological and geographical features of the South China Sea results in abundant mineral resources, natural gas and oil which naturally attracts policy makers, environmentalists, governmental authorities and geoscientists. South China Sea belongs to the type of marginal seas adjacent to the continents. The main part of the transition zones (continental and oceanic margins) is located on the western periphery of the Pacific Ocean. 


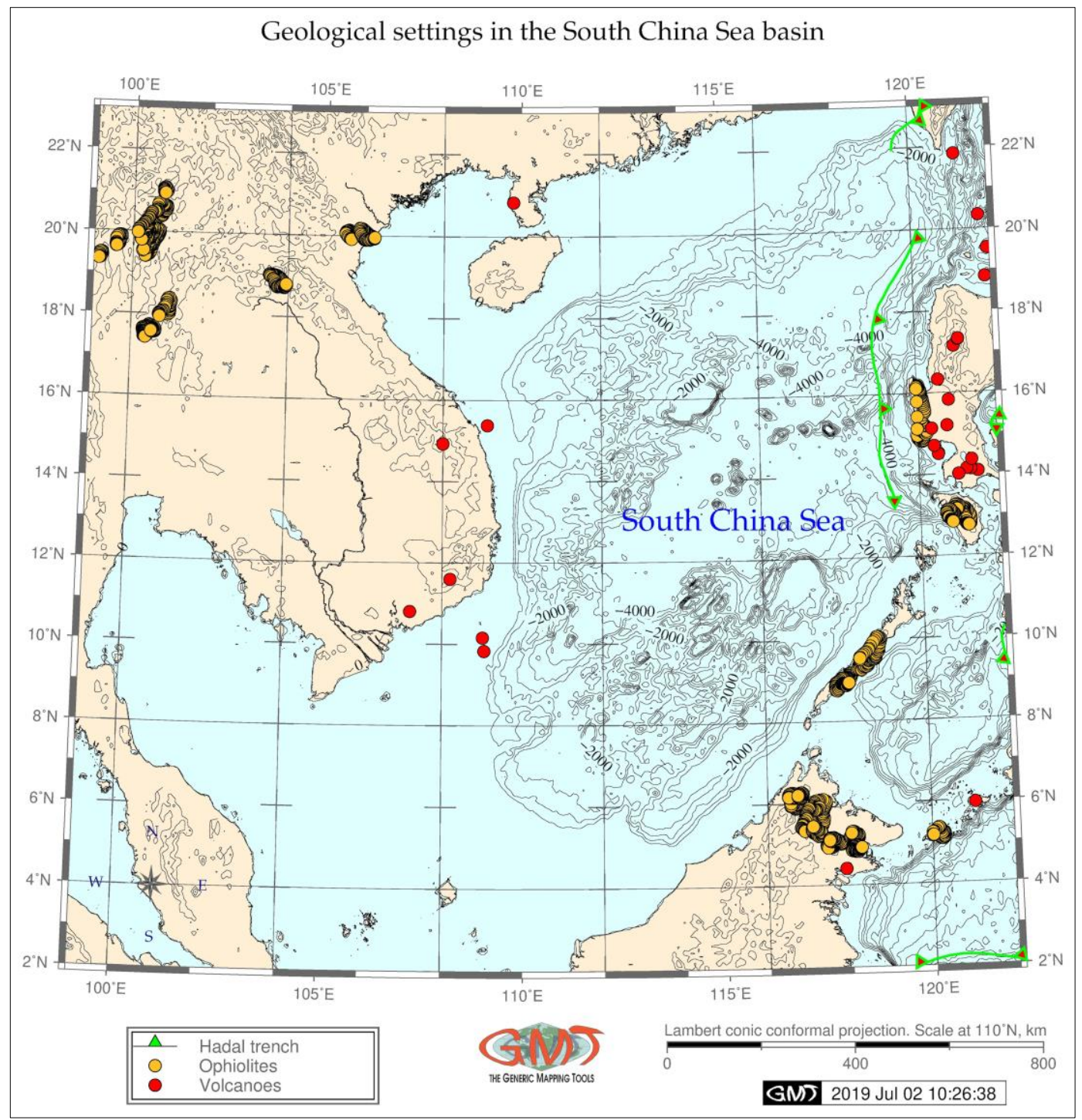

Figure 2. Geologic map of the South China Sea: location of the volcanoes, ophiolites and hadal trenches (Source: Author)

There are several morphological types of crust that differ in the position of the basins of the seas. Besides South China, examples of other marginal seas include, for instance, Bering Sea, Sea of Okhotsk, and Sea of Japan. South China Sea belongs to the transitional zones of the western part of the Pacific Ocean. This region is notable for a very complex geomorphology with dissected area of island arcs and massifs, shallow shelves and deep basins, ridges and gutters, located between the Southeast Asia and Australia, including Philippine Islands. The shelf in the South China Sea has a significant width in the northern and southern parts and is noticeably reduced along the coast of Vietnam. The prevailing depths range from 60 to $100 \mathrm{~m}$, and $<50 \mathrm{~m}$ between the islands. The surface of the shelf is mostly levelled, with exception in the coastal zones and near the small islands where it is complicated by numerous coral reefs.

The shelf area with the continental crust is noticeably larger in South China Sea comparing, for example, to the Sea of Japan. A subcontinental crust with a thickness of more than $30 \mathrm{~km}$ lies 
under the Philippine Islands. A suboceanic crust with a thickness of about 12-20 km lies under the bottom of the sea basin, and becomes noticeably thicker on the submarine elevations. A complex combination of the subcontinental and suboceanic crust can be seen to the south from the Philippine Archipelago. The crust under the islands and underwater ridges has a thickness of more than $25 \mathrm{~km}$ and consists of a relatively thin volcanic layer and two main layers with seismic speeds of 5.7-6.2 and 6.7-6.9 km/s. On the contrary, the thickness of the crust decreases to $10 \mathrm{~km}$ in the depressions, such as basins of Sudu, Sulawesi, Banda and others. Its structure is comprised by layers with seismic velocities of about 5.0 and $6.4-6.9 \mathrm{~km} / \mathrm{s}$ as well as sedimentation layer (Murauchi and Ludwig, 1973).

South China Sea has the enclosed nature of the basin, the geometric shape similar to a rhombus, with long axis in North-East-South-West direction. Its length stretches to ca. $3100 \mathrm{~km}$, width of ca. $1200 \mathrm{~km}$, area of ca. 350,104 $\mathrm{km}^{2}$ (Becker and Sandwell, 2008). The average bathymetric depth is $1212 \mathrm{~m}$, and the deepest point is located at the southeast end of Manila trench with depth of $5377 \mathrm{~m}$ (Lafond, 1966). South China Sea is divided from the periphery to its central part. The continental shelf and island shelf area covers $48.14 \%$, the continental slope while island slope area $36.12 \%$, and sea basin area $15.74 \%$, respectively (Taylor and Hayes, 1983).

The ETOPO1 global relief model was modeled (figure 1) using Generic Mapping Tools (GMT) cartographic scripting toolset using 'grdimage' module (Wessel and Smith, 1995). The bathymetry of the South China Sea was visualized using 'geo' color palette. The original data is derived from the sea-surface satellite altimetry measurements and ocean soundings provided by numerous global geospatial sources. The ETOPO1 includes existing bathymetry data set with 1 min resolution (Smith, 1993) and uses interpolated gravity values (Smith and Sandwell, 1995). The shoreline was added using coastal vector layer embedded in GMT (Wessel and Smith, 1996).

The continental slope in the South China Sea has a complex stepwise block structure, descending in a staircase-like pattern to the bottom of the basin, which occupies the central part of the South China Sea. In its northern, western and southern parts, the slope is complicated by the marginal plateaus. Notable geomorphological features include the Dongshandao reef, the Paracel islands and Nansha islands with surrounding coral reefs, rise on one of these plateaus. A particularly complicated structure of the submarine relief is observed on the Nansha Plateau, where the straits between the islands and reefs are formed by very steep canyons and troughs with depths reaching up to 1700-2000 m. Seamounts are rising at the seafloor of the South China Sea basin, where the depths are 4200-4400 m (and >5000 m near the Philippine Islands). Seamounts are especially notable in the north-eastern part of the South China Sea with elevations up to 3000$4000 \mathrm{~m}$.

The tectonics of the South China Sea has complex character. This, the crustal type of the South China Sea continental margins is composed of the continental, oceanic and transitional crust (Taylor and Hayes, 1980). The distribution of the continental crust is mainly adjusting the land areas while new oceanic crust appears in the continental crust. The oceanic crust is mainly located near the ocean borders. The transitional crust in continental shelf and continental slope areas encompass $30-32 \mathrm{~km}$, the northern continental shelf region is about $28-24 \mathrm{~km}$, and the north of Dongsha Islands increases to $30-32 \mathrm{~km}$, and southwestern continental shelf crust thickness is 24$26 \mathrm{~km}$ (Yincan et al., 2017). The central basin of the South China Sea is presented by the oceanic crust with thickness of $6-8.5 \mathrm{~km}$ and with the average thickness of $6.8 \mathrm{~km}$. According to the characteristics of crust, the South China Sea can be divided into blocks: northwest, southeast, central basin and Luzon-Palawan Island arc fold belt. South China Sea is notable for the high seismisity (Dubinin and Ushakov, 2001). The historical development of the tectonics os South China Sea includes several processes: during the Meozoic, the tectonic movement of lithosphere in South China Sea presented the assembly and the accretion of plates or terrains, thereafter the small plates or terrains gradually integrated and merged into a unified plate which formed a part of the Eurasian Plate (Jin, 1992). 


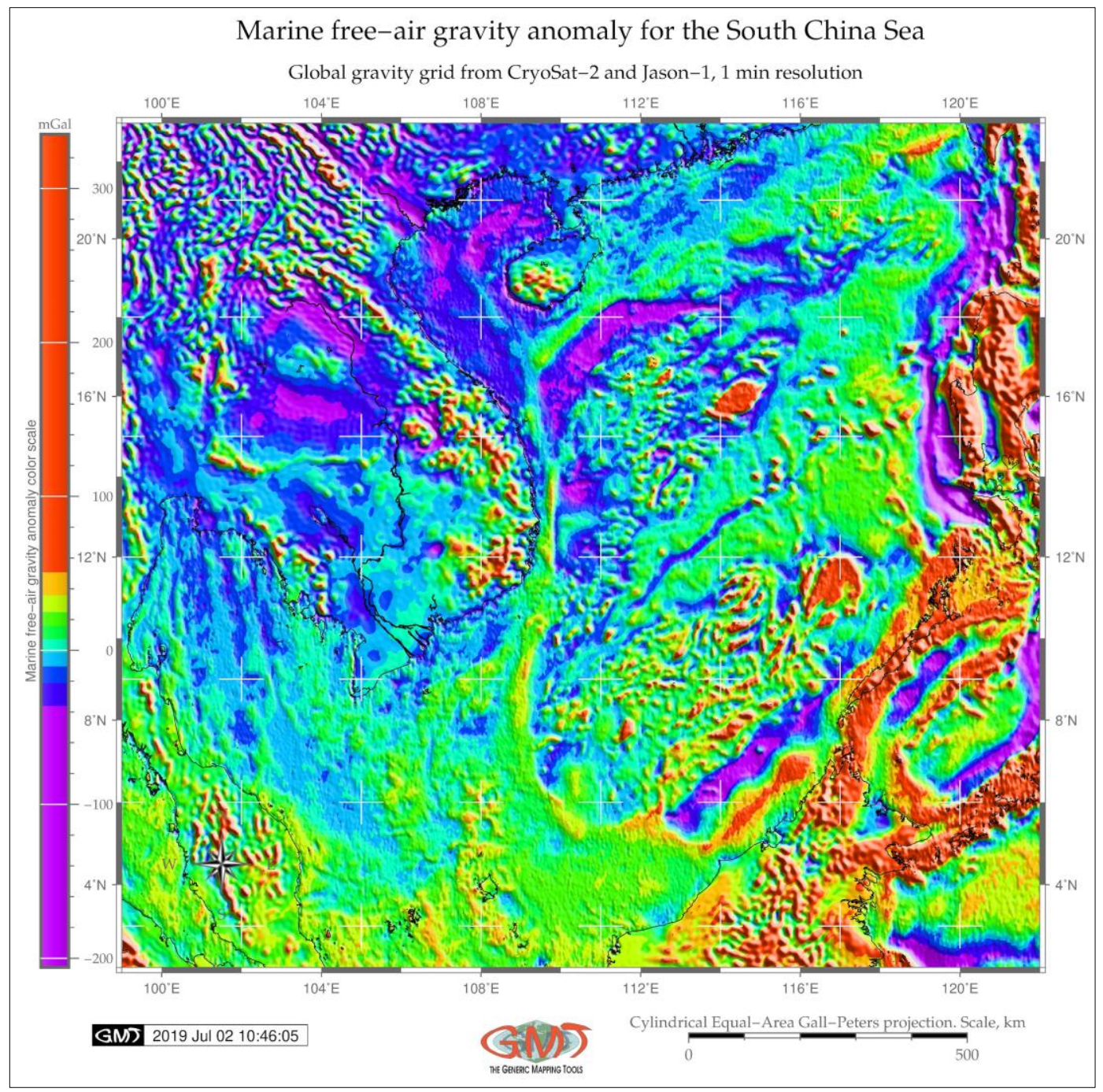

Figure 3. Marine free-air gravity map of the of the South China Sea (Source: Author)

South China Sea basin was formed as a result of the continental margin rifting and spreading. The continental lithosphere was attenuated to the extent of plate spreading indicated by the geomagnetic pattern with east-west trend. The southern coast of the China is characterized by numerous postglacial embayments and near shore islands. Sedimentation is controlled largely by moderate tidal currents depositing fine-grained sediments (Gurvich, 1998). South Sea is characterized by numerous islands that have been submerged during the last transgression. 


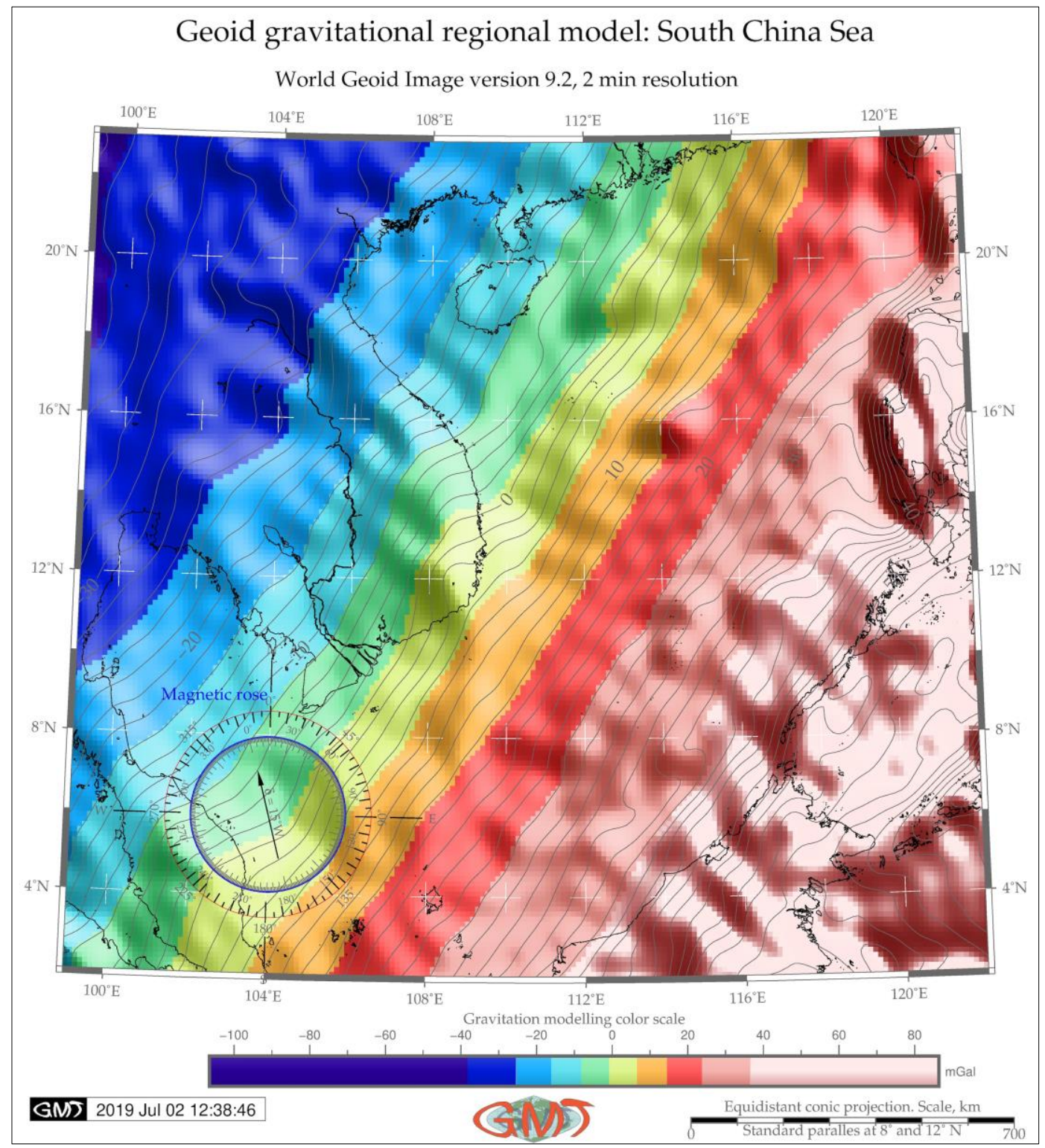

Figure 4. Map model of the geoid on the region of the South China Sea (Source: Author)

Shallow subsurface mapping using high-resolution seismic profiling has revealed that the sea is characterized by complex incised valley systems and transgressive deposits during the rise in sea level. The notable landform of the South China Sea is the Philippine Trench and the Manila Trench which stretches up to $10 \mathrm{~km}$. Generally, the surface of the basement on the shelf in a South China Sea has a depth of less than $1 \mathrm{~km}$, complicated only by minor local depressions. At the shelf edge, it descends along a complex stepwise block ledge to the bottom of the basin, while the basement surface of the Cenozoic structures of the Philippine Islands descends along a simpler ledge. The surface of the basement at the seafloor of the basin has depths of over $5 \mathrm{~km}$. It is complicated in the southern part of the South China Sea by the raising of the Nansha (Spratly) 
Islands, where its depths do not exceed $2 \mathrm{~km}$. The Spratly Islands, one of the major archipelagos in the South China Sea, consist of islands of accumulated biogenic carbonate which lie upon the crests of the submarine ridges, uplifted fault blocks. Geologically, these horsts present part of a series of parallel rotated fault-blocks.

South China Sea has complicated tectonic and sedimentation history. Tectonically, the basin of the South China Sea has developed between the terrains (continental fragments) rifted from Asian continent. Therefore, the sedimentation has also occurred between and on the submerged continental fragments. The unique feature that distinguishes the South China Sea among other Pacific marginal seas is the fact that South China Sea is surrounded by land territories with intense erosion. Therefore, the abyssal deposits are mainly composed of the terrigenous clastic sediments and biogenesis carbonate in various proportions (Kennett, 1982). Hence, the sedimentation rate in the South China Sea is much higher than in the open Pacific. Locally, the sedimentation rate of pelagic sediment lower than $1 \mathrm{~cm} \cdot \mathrm{ka}-1$ in the Pacific (Lisitzin, 1972), and the pelagic areas have ca. 10\% lower sedimentation rate than in deep South China Sea. Generally, the thickness of the Meso-Cenozoic sedimentary cover in the deepest parts of the basin of the sea $>1 \mathrm{~km}$. The thickness of the cover is noticeably reduced at the tops of numerous uplifts of the seafloor of the sea. Here, the sedimentary cover is mainly represented by the Cenozoic coral limestones. A similar situation is observed in the numerous basins of the Malay archipelago. Cenozoic terrigenous sediments with a thickness of up to $1 \mathrm{~km}$ or more are predominant here, which are reduced and replaced by coral limestones at the elevations of the bottom.

Geoid gravitational model (figure 4) shows the gradual increase in the gravitation values from the north-west to the south-east directions. The values lies in the interval between -100 to 80 $\mathrm{mGal}$ with the lowest values on the continent (coloured blue). On the contrary, the highest values reaching $80 \mathrm{mGal}$ are located in the area near Philippine archipelago that is east and south-east area on the map. The central part of the South China Sea has gravity values in ranges 0-8 (segment coloured light yellow), following by 8012 (coloured orange), than 12-24 (coloured red), as shown on figure 4. On the shelf of the South China Sea, developed linear magnetic anomalies are associated with Precambrian anticlinal base structures. The same situation is observed in the basin near the Philippine Islands, where a sharp change in short-period anomalies by a calm field is clearly visible (figure 3). The linear magnetic anomalies of the basin resemble oceanic ones and may indicate a suboceanic type of the Earth's crust in the region of the South China Sea.

\section{DISCUSSION AND RECOMMENTATIONS}

Currently, China has extensive and special interest in the coastal areas and marine geologic investigations. In order to realize these benefits, it has taken many active measures on research on the South China Sea. Continuous efforts have been made by the government of China in the South China Sea region, aimed to explore hydrocarbon in the concession blocks. Thus, attempts were made by the Chinese Institute of Geology projects since early 1960s to obtain data on the geological structure of the shallow portions of the South China Sea. Following questions were of particular attention for research on South China Sea area: the geologic structure and tectonics, general and sequence stratigraphy, sedimentary facies and processes, origin and development of the marginal seas include shelf areas with a narrow continental shelf and deep basins, rocky embayment (Ben-Avraham, 1989; Royal Observatory Hong Kong, 1989; Zhu, 1987). These research problems were recently investigated by the Chinese authorities. Moreover, special research projects studied marine geological structure drilled holes throughout the South China Sea basin. Shallow subsurface mapping using high-frequency profiling and deep cores into the Holocene/Pleistocene boundary have been made to reveal late Quaternary depositional processes and sequence stratigraphy in this unique epicontinental sea (Kudrass et al., 1986; Wan and Zhu, 1989; Wu, 1988).

Research plan of marine geology progress in China includes following tasks in the development of the marine geology program in the South China Sea are: 
- to perform applied research in oceanography and marine geology;

- to promote the efficient use of coastal and ocean resources;

- to undertake comprehensive surveys and studies of South China Sea;

- to conduct research in polar and tropical regions: Antarctica and Pacific Ocean;

- to develop technologies related to the coastal and harbour engineering;

- to develop ship engineering, ocean engineering, and maritime safety;

- to support and cooperate with agencies, universities and private industries towards the development of marine resources and the protection of the ocean environment;

- to participate in the international cooperation on oceanographic research projects.

Planning and organization of the geological research and survey is conducted by the Ministry of Geology P.R.C. The regional departments are organized through the territorial geological management and agencies, as well as ministries related to development of mineral resources and construction. Research work in marine geology domain is carried out by multiple research centers, institutes and laboratories and of some other ministries and Chinese Academy of Sciences. A series of periodic scientific geological journals reporting marine expedition results and outcomes published regularly with the most important publishing house in Beijing (Ru, 1987; Zhang, 1989). Since 1960s China is intensively developing the geology of the seafloor investigations in the South China Sea region, with particular focus on the industrial mineral development of the large areas in the continental shelf. The geophysical methods are widely used in the research on geology of the seafloor. Recently, high-latitude drilling is being performed with specially equipped vessels.

Recent achievement in the domain of marine geological research focused on the region of South China Sea includes several levels successfully reached in the Chinese marine geology program:

1. Equipment of the research centers by specific data on the marine geology across the coastal areas of the country (main centers: Qingdao, Hangzhou, Guangzhou, and Xiamen);

2. Adapted and development methodologies of the seafloor survey with updated technologies, devices, sensors, and specialists to achieve high standards;

3. Marine geo-information data systems aimed to perform bathymetric mapping by enriching digital models with data get during ship cruises including examples of numerical data analysis in marine applications;

4. Updated technical assistance by the multi-beam data received during the cruises. Storage of GIS data in data centers enables to support decision making and bathymetric mapping.

Nowadays a great variety of research and investigations in the coastal environments and marine geology of South China Sea region is performed by Chinese research centers. Among recent achievement advanced GIS technologies (Schenke and Lemenkova, 2008; Kuhn et al., 2006; Klaučo et al., 2013, 2014, 2017; Gauger et al., 2007) should be recommended for mapping and data analysis. There are improvements and progress in the development of marine geology program in the South China Sea region. Highlighted recommendations directions specifically for the South China Sea region include:

- systematic high precision and accuracy mapping of the seafloor of the South China Sea;

- regular sea expeditions should acquire geodata, seabed sediments, and data on geomorphology, mineral resources, geochemistry, geophysical parameters, surface and subsurface samples and other geological data around the aquatory of South China Sea;

- detailed documentation of the observation samples collected from the offshore cruises around the South China Sea to be compiled to enable prognosis or evaluations and comparison with existing data (GEBCO, ETOPO1, SRTM);

- combination of the long term multi-spectral satellite images and GIS data in the marine resources prognosis mapping has great application potential for the monitoring process;

- the in-situ data, received from the $\mathrm{R} / \mathrm{V}$ expeditions is to be processed using advanced analytical tools and algorithms, published in various reports: Python (Lin, 2008; Marta-Almeida et 
al., 2011; Oliphant, 2007; Lemenkova, 2019a; Millman and Aivazis, 2011), R (R Development Core Team, 2014; Vermeesch et al., 2016), GMT (Wessel and Smith, 1995) that can generate data on the geological situation of the marine geology in the South China Sea region;

- developing ocean big data center focused on the marine geology around the South China Sea has to be created. The data should be multi-source and actual with regular updates. This will provide useful insight for marine geological management and gain content;

- implementation of the oceans policy integrated as a coordinating agency with subordinated institutions focused on the marine research with transparent coordination;

- establishment of the benefit-cost analysis aimed at systematical assessment of the efficiency of public policies in marine geology. The benefit-cost analysis should be applied before new equipment is ordered, to assess advantages and financial drawbacks;

- organizing regular conferences, meetings, panels, aimed at the multi-disciplinary discussions on specific problems concerned South China Sea at the international level;

- close cooperation with neighboring countries of the basin of the South China Sea, which is beneficial for the development of the South China marine program;

- advanced development of the seafloor mapping in the region of South China Sea aimed at precise bathymetric mapping for navigation and research.

\section{CONCLUSION}

In China, as a result of recent scientific development, several ocean research centres were established in China, financed and ruled by the Chinese government. These centres conduct research on the Pacific Ocean and Chinese seas in general and South China Sea in particular (table 1). These centres have driven development of the marine sciences and technology of China for several decades since establishment. Ocean centres and research institutes of China have several branches located within the country, all of which fulfil necessary functions in marine geology research and development. Important marine research centre in the field of maritime geology is located in Hangzhou: the Second Institute of Oceanography SOA. The Chinese CAS approved a bill to establish a research centre to help advance the country's marine geology sector. Research facilities of the South China Sea Institute of Oceanology Hangzhou widely use towed devices above the bottom, e.g. dredging. Remote sensing and GIS methods as well as data analysis by Python and R programming libraries are also widely used. Research interests of CAS, Guangzhou as a major research centre for marine geology in China encompass the area surrounding the South China Sea and the region of the western Pacific Ocean (e.g. Mariana Trench, Philippine Trench). However, it also includes fundamental research in Antarctica. The main areas of interest are geological and geophysical science, the life sciences, and climate science. The CAS owns the research vessels R/V, used to supply the year-round ocean investigations.

Examples of publications with a focus on the marine geology are as follows: China Sea (Chen et al., 1990; Qinhuan et al., 1989; Yulian and Liao, 1983; Zhang and Huang, 1990), Kermadec and Tonga Trenches (Lemenkova, 2019e), Philippine Trench, Mariana Trench, Kuril-Kamchatka Trench (Lemenkova, 2019f), Barents and Pechora Seas (Suetova et al., 2005).

Table 1. Key CAS and research centres with special focus on ocean and marine research (Data source: Web)

\begin{tabular}{|l|l|l|}
\hline Name of the institution & City & Province \\
\hline $\begin{array}{l}\text { State Key Laboratory of Satellite Ocean Environment } \\
\text { Dynamics-SOED }\end{array}$ & Hangzhou & Zhejiang \\
\hline Institute of Oceanology, CAS & Qingdao & Shandong \\
\hline First Institute of Oceanography SOA & Qingdao & Shandong \\
\hline Second Institute of Oceanography SOA & Hangzhou & Zhejiang \\
\hline Third Institute of Oceanography SOA & Xiamen & Fujian \\
\hline South China Sea Institute Of Oceanology & Xiamen & Fujian \\
\hline
\end{tabular}




\begin{tabular}{|l|l|l|} 
China Ocean Development Research centre & Qingdao & Shandong \\
\hline Ocean University of China & Qingdao & Shandong \\
\hline Shanghai Ocean University & Shanghai & Shanghai \\
\hline Shanghai Maritime University & Shanghai & Shanghai \\
\hline Dalian Maritime University & Dalian & Liaoning \\
\hline $\begin{array}{l}\text { State Key Laboratory of Tropical Oceanology, South China } \\
\text { Sea Institute of Oceanology, CAS }\end{array}$ & Guangzhou & Guangdong \\
\hline
\end{tabular}

The scope of these and others research encompasses various topics of the marine environment, navigation and mapping. State decisions in the field of maritime activities, such as administrative, legislative reforms, are taken on the basis of the results of operations of this body. A wide range of fisheries research is carried out at the fisheries centres and branches (Mallory, 2016; 2015). The most progressive tool used in marine geology seafloor investigations if multibean techniques. As a result of the publication activities, the geology of the South China Sea is well described in numerous reports. This is an area for further detailed studies of high-resolution and high accuracy sequence stratigraphy. A number of offshore exploratory wells have also been drilled by governmental companies, revealing high hydrocarbon potential.

\section{Acknowledgements}

This research was funded by the China Scholarship Council (CSC), State Oceanic Administration (SOA), Marine Scholarship of China, Grant Nr. 2016SOA002, P.R.C.

\section{REFERENCES}

Ben-Avraham, Z. (1989). Multiple opening and closing of the eastern Mediterranean and South China basins. Tectonics, 8 (2), 351-362

Butuzova, G.O. (2003). Hydrothermal-sedimentary ore formation in the world the ocean. M.: GEOS. 156 pp. (in Russian). Cai, A. (1989). Beach cycle and coastal engineering. The Ocean Engineering, 7 (3), 57-64 (in Chinese).

Caress, D.W. \& Chayes, D.N. (1996). Improved processing of Hydrosweep DS multibeam data on the R/V Maurice Ewing. Marine Geophysical Research 18, 631-650. doi:10.1007/bf00313878

Chen, W.B., Jennerjahn, T.C., \& Xu, V. (1990). A preliminary study of the sediment trap samples frame the South China Sea. A report on the work done at the Institute of Biogeochemistry and Marine Chemistry. University of Hamburg.

Dubinin, E.P., \& Ushakov, S.A. (2001). Oceanic rifgogenesis. M.: GEOS, 293 pp (in Russian).

Gauger, S., Kuhn, G., Gohl, K., Feigl, T., Lemenkova, P., \& Hillenbrand, C.-D. (2007). Swath-bathymetric mapping. In Gohl, K. The expedition ANTARKTIS-XXIII/4 of the Research Vessel 'Polarstern' in 2006. Reports on Polar and Marine Research, 557, 38-45.

Gurvich, E.G. (1998). Metalliferous sediments in the World Ocean. M.: Scientific World. 340 pp (in Russian)

Heuret, A. \& Lallemand, S. (2005). Plate motions, slab dynamics and back-arc deformation. Physics of the Earth and Planetary Interiors, 149, 31-51.

Jin, Q.H. (1989). Geology and Petroleum Resources in the South China Sea. Geol. Publ. House, Beijing, 417 pp (in Chinese).

Jin, X. \& Ke, C. (1990). Geophysical features and geological evolution of the South China Sea. Asian Marine Geology, 147-155, China Ocean Press, Beijing.

Jin, Q. (1992). Proceedings of the Symposium on the Recent Contributions to the Geological History of the South China Sea. Marine Geology and Geophysics of the South China Sea. Ed.: X. Jin, H. Kudrass, G. Pautot. China Ocean Press. ISBN 7-5027-1915-6 / K.66

Kennett, J.P. (1982). Marine Geology. New York: Prentice-Hall.

Klaučo, M., Gregorová, B., Stankov, U., Marković, V., \& Lemenkova, P. (2013). Determination of ecological significance based on geostatistical assessment: a case study from the Slovak Natura 2000 protected area. Central European Journal of Geosciences, 5(1), 28-42.

Klaučo, M., Gregorová, B., Stankov, U., Marković, V. \& Lemenkova, P. (2014). Landscape metrics as indicator for ecological significance: assessment of Sitno Natura 2000 sites, Slovakia. Ecology and Environmental Protection. Proceedings of the International Conference, March 19-20, 2014. Minsk, Belarus, 85-90.

Klaučo, M., Gregorová, B., Stankov, U., Marković, V., \& Lemenkova, P. (2017). Land planning as a support for sustainable development based on tourism: A case study of Slovak Rural Region. Environmental Engineering and Management Journal, 2(16), 449-458.

Kudrass, H.R., Weidicke, M., Cepek, P., Kreuzer, H. \& Muller, P. (1986). Mesozoic and Cenozoic rocks dredged from the South China Sea (Reed Bank area) and Sulu Sea and their significance for plate-tectonic reconstructions. Marine Petroleum Geology, 3, 19-30. 
Kuhn, G., Hass, C., Kober, M., Petitat, M., Feigl, T., Hillenbrand, C.D., Kruger, S., Forwick, M., Gauger, S., \& Lemenkova, P. (2006). The response of quaternary climatic cycles in the South-East Pacific: development of the opal belt and dynamics behavior of the West Antarctic ice sheet. Expeditionsprogramm Nr. 75, FS Polarstern, ANT-XXIII/4, AWI for Polar and Marine Research. URL: https://epic.awi.de/id/eprint/29852/1/PE_75.pdf (accessed on 4 March 2020).

Lafond, E.C. (1966). South China Sea. The Encyclopedia of Oceanography, Reinhold Pub. Corp., New York, 829-836.

Lemenkova, P. (2019a). Statistical Analysis of the Mariana Trench Geomorphology Using R Programming Language. Geodesy and Cartography, 45(2), 57-84.

Lemenkova, P. (2019b). Automatic Data Processing for Visualising Yap and Palau Trenches by Generic Mapping Tools. Cartographic Letters, 27 (2), 72-89.

Lemenkova, P. (2019c). Geomorphological modelling and mapping of the Peru-Chile Trench by GMT. Polish Cartographical Review, 51(4), 181-194.

Lemenkova, P. (2019d). Topographic surface modelling using raster grid datasets by GMT: example of the KurilKamchatka Trench, Pacific Ocean. Reports on Geodesy and Geoinformatics, 108, 9-22.

Lemenkova, P. (2019e). GMT Based Comparative Analysis and Geomorphological Mapping of the Kermadec and Tonga Trenches, Southwest Pacific Ocean. Geographia Technica, 14(2), 39-48.

Lemenkova, P. (2019f). AWK and GNU Octave Programming Languages Integrated with Generic Mapping Tools for Geomorphological Analysis. GeoScience Engineering, 65(4), 1-22.

Lin, Y., \& Kangming, L. (1983). The wave study in the Taiwan Strait. Taiwan Strait, 2 (1), 20-26. Niino, H. and O.K.

Lin, J. W.B. (2008). qtcm 0.1.2: a Python implementation of the Neelin-Zeng quasi-equilibrium tropical circulation model. Geoscientific Model Development, 1, 315-344. doi: 10.5194/gmd-2-1-2009.

Lisitsyn, A.P., Bogdanov, Y. A., \& Gurvich, E. G. (1990). Hydrothermal Formations at Ocean Rift Zones, Nauka (in Russian).

Lisitzin, A.P. (1972). Sedimentation in the World Ocean. S.E.P.M., 17, (in Russian).

Mallory, T.G. (2016). Fisheries Subsidies in China: Quantitative and Qualitative Assessment of Policy Coherence and Effectiveness. Marine Policy, 68, 74-82.

Mallory, T.G. (2015). Preparing for the Ocean Century: China's Changing Political Institutions for Ocean Governance and Maritime Development. Issues and Studies, 51 (2), 111-138.

Marta-Almeida, M., Ruiz-Villarreal, M., Otero, P., Cobas, M., Peliz, A., Nolasco, R., Cirano, M. \& Pereira, J. (2011). OOF3: A Python engine for automating regional and coastal ocean forecasts. Environmental Modelling and Software, 26, 680-682. doi: 10.1016/j.envsoft.2010.11.015

Millman, K. J. \& Aivazis, M. (2011). Python for Scientists and Engineers, 13, 9-12. doi: 10.1109/MCSE.2011.36

Morgan, V. (1974) Oceanic uplifts, deep-sea trenches, large faults and crust blocks. New global tectonics. M.: Mir.

Murauchi, S., Ludwig, W.J., \& Den, N. (1973). Structure of the Sulu Sea and the Celebes Sea. Journal of Geophysical Research, 78(17), 3437-3447.

Oliphant, T.E. (2007). Python for scientific computing. Computing in Science and Engineering, 9, 10-20. doi: 10.1109/MCSE.2007.58

Pushcharovsky, Yu. M., \& Neprochnov, Yu. P. (1984). The structure of the bottom of the north-west of the Pacific Ocean (geophysics, magmatism, tectonics). M.: Nauka, 232 pp (in Russian)

R Development Core Team (2014). R: a Language and Environment for Statistical Computing. R Foundation for Statistical Computing. URL: http://www.R-project.org (accessed: 31 March 2020).

Ren, J.S., Jiang, C.F., Zhang, Z.K., \& Qing, D.Y. (1980). Geotectonics of China and its evolution. Science Press, Beijing (in Chinese)

Royal Observatory Hong Kong (1989). Marine climatological summary charts for the South China Sea 1985. Royal Observatory, Hong Kong, 137 p.

$\mathrm{Ru}, \mathrm{K}$. (1987). The plate tectonic analysis of marginal basin in northern South China Sea. In: International Symposium on Petroleum Geology of Northern Continental Shelf in South China Sea, 632- 641, The Chinese Petroleum Society (in Chinese).

Becker, J.J., \& Sandwell, D.T. (2008). Global Estimates Of Seafloor Slope From Single-Beam Ship Soundings, Journal of Geophysical Research, 113, C05028, doi:10.1029/2006JC003879.

Schenke, H.W. \& Lemenkova, P. (2008). Zur Frage der Meeresboden-Kartographie: Die Nutzung von AutoTrace Digitizer für die Vektorisierung der Bathymetrischen Daten in der Petschora-See. Hydrographische Nachrichten, 81, 16-21.

Smith, W.H.F. (1993). On the accuracy of digital bathymetric data. Journal of Geophysical Research, 98(B6), 9591-9603.

Smith, W.H.F., \& Sandwell, D.T. (1995). Marine gravity field from declassified Geosat and ERS-1 altimetry. EOS Transactions of the American Geophysical Union, 76, Fall Mtng Suppl, F156.

Suetova, I. A., Ushakova L. A., \& Lemenkova, P. (2005). Geoinformation mapping of the Barents and Pechora Seas. Geography and Natural Resources, 4, 138-142.

Taylor, B., \& Hayes, D.E. (1980). The Tectonic Evolution of the South China Basin. Geophysical Monograph, 23, 89-104.

Taylor, B., \& Hayes, D.E. (1983). The origin and history of the South China Basin. Geophysical Monograph, $27,23-56$.

Vermeesch, P., Resentini, A., \& Garzanti, E. (2016). An R package for statistical provenance analysis. Sedimentary Geology, 336, 14-25. doi: 10.1016/j.sedgeo.2016.01.009

Wan, T. \& Zhu, H. (1989). The tectonic stress field of the Cretaceous-Early 'Eocene in China. Acta Geologiea Sinica, 63 (1), 14-25 (in Chinese).

Wessel, P., \& Smith, W.H.F. (1996). A Global Self-consistent, Hierarchical, High-resolution Shoreline Database. Journal of Geophysical Research, 101, 8741-8743. 
Wessel, P., \& Smith, W.H.F. (1995). New version of the Generic Mapping Tools released. EOS Transactions of the American Geophysical Union, 76 (33), 329.

Wu, J. (1988). Cenozoic basins of the South China Sea. Episodes, 11 (2), 91-96.

Wyrtki, K. (1961). Physical oceanography in southeast Asian waters. Naga report, scientific results of marine investigations of the South China Sea and the Gulf of Thailand, 1959-1961.

Yincan, Y., et al. (2017). Marine Geographic and Geological Environment of China. Chapter 2. Marine Geo-Hazards in China, China Ocean Press, 35-75. doi: 10.1016/B978-0-12-812726-1.00002-4

Zhang, J. (1989). Preliminary study on the topography and sediment characteristics of the Taiwan Strait and adjacent area. Studia Marine Science, 30, Science Press, Beijing, China, 1-17 (in Chinese).

Zhang, Q. \& Huang, B. (1990). An overview of gases and source rocks from the area around the Hainan Island, offshore South China. China Offshore Oil and Gas (Geology), 4 (1), 5-13 (in Chinese).

Zhu, X. (1987). On the evolution of continental margins of China. Marine Geology and Quaternary Geology, 7 (3), 115119 (in Chinese).

Submitted:

April 4, 2020
Revised:

May 252020
Accepted and published online

June 25, 2020 